\title{
Redox Properties of Grape Wine Skin Extracts from The Šumadija Region - An Electron Paramagnetic Resonance Study
}

\author{
Đura J. Nakarada ${ }^{1}, S_{\text {đan }}$ Z. Marković ${ }^{1,2}$, Milan D. Popović ${ }^{1}$, \\ Milena S. Dimitrijevićc ${ }^{1,3}$, Aleksandra A. Rakić ${ }^{1}$, Miloš D. Mojović ${ }^{1}$ \\ ${ }^{1}$ Faculty of Physical Chemistry, University of Belgrade, Center for Physical Chemistry of Bio- \\ logical Systems, Belgrade, Serbia \\ ${ }^{2}$ Clinical Centre of Serbia, Belgrade, Serbia \\ ${ }^{3}$ Institute for Multidisciplinary Research, University of Belgrade, Belgrade, Serbia
}

\section{SUMMARY}

Introduction: Comprising of a unique combination of bioactive polyphenol compounds, grapes are shown to have a beneficial effect on the skin as well as the whole body. They exhibit high antioxidative and antiradical activity through mechanisms of heavy metals chelation, scavenging reactive oxygen species, inhibiting lipid peroxidation, and preserving the integrity of the cell membranes. In the winemaking industry, after crushing and pressing, grape pomace (stems, seeds, pulp, and skin) is removed as a by-product. This valuable source of bioactive compounds is often treated as animal food, compost, raw material in the brewery, but unfortunately mostly disposed of as unusable waste.

Aim: The aim of this study was to compare redox properties of absolute $\mathrm{EtOH}, 50 \% \mathrm{EtOH}$, and $\mathrm{H}_{2} \mathrm{O}$ grape wine skin extracts in a way of scavenging DPPH radicals, showing that biowaste obtained from grape wineskins could be used as an immense source of bioactive compounds with high antiradical activity.

Material and Methods: Electron Paramagnetic Resonance (EPR) spectroscopy was used to detect the activity of grape skin extracts toward DPPH radicals and UHPLC-DAD MS/MS analysis to separate, identify and quantify their active components.

Results: The results show that Cabernet Sauvignon and Pinot Blanc grape skin extracts have unexpectedly large potential to remove DPPH radicals from the system. Having in mind the concentration of redox-active components obtained by UHPLC-DAD MS/MS analysis and presented EPR results, there is strong evidence that primarily quercetin 3-0-glucoside, as well as kaempferol 3-0-glucoside, isorhamnetin 3-0-glucoside, kaempferol 7-0-glucoside supplemented with catechin and rutin are responsible for the antioxidative capacity of extracts.

Conclusions: This study demonstrates that extracts obtained from grape skins, initially intended as biowaste, exhibit high antiradical activity. The largest quantity of the most redox-active components could be found in $50 \% \mathrm{EtOH}$ extracts, which we propose to be the starting material for making potent redox-active cosmetic products and dietary supplements.

Keywords: Grape skin extracts, Antioxidative activity, Electron Paramagnetic Resonance (EPR) spectroscopy, UHPLC-DAD MS/MS analysis 


\section{INTRODUCTION}

Living in an unhealthy environment and leading a stressful life in demanding times, the modern individual is becoming interested in using plain natural resources to build up their immune system, skincare, and improve health.

The grape has been considered a divine fruit since ancient times. As mankind has acquired knowledge and experience, every constituent part of the grape plant has been expanded to its application in various areas of human activities: ecology [1], energetics [24], medicine [5-7], cosmetics [5,8], pharmacy $[5,9]$, food industry $[5,10,11]$, agriculture $[5,12]$, etc. A wide range of nutritious compounds (carbohydrates, fibers, vitamins, minerals, fatty acids, and bioactive phytochemicals) make grapes the most exploited part of the whole grapevine. Bioactive compounds from grapes are proved to have beneficial effects when applied locally on the skin as well as systematically to the whole body [10]. The extraordinary reputation of wine is actually based on a unique combination and properties of the premium family of bioactive compounds, polyphenols [13]. They exhibit high antioxidative and antiradical activity through mechanisms of heavy metals chelation, scavenging reactive oxygen species, inhibiting lipid peroxidation, and the decrease in the fluidity of the membranes which hinders the diffusion of free radicals into the cell [14].

Polyphenol antioxidant activities in the human body occur in a wide range of preventive and therapeutic effects including antitumor, anti-microbial, cardioprotective, antimutagen, anti-proliferative, anti-aging, and anti-inflammatory effects. The bioactive grape compounds additionally improve appearance, health, and protective skin function, by acting locally as an anti-cellulite agent, improving circulation, preventing and reducing skin hyperpigmentation (freckles, age pigment, and melasma), collagen degradation and denaturation, etc. Furthermore, the influence of antioxidant defense at all levels (cell, tissue organs, system of organs) has also been studied concerning peristalsis in the digestive tract $[15,16]$, myocardial infarction $[17,18]$, and reproductive organs $[19,20]$. In other words, there is no cell, tissue or organ that does not enjoy the beneficial effects of natural nontoxic unique super-cocktails of grape bioactive substances.
In the winemaking industry, after crushing, pressing (and for black wines fermentation) until the must is formed, grape pomace (stems, seeds, pulp, and skin), which constitute around $20 \mathrm{w} \%$ of grapes, is removed as a by-product. This valuable source of bioactive compounds is often treated as animal food, compost, raw material in a brewery, but mostly disposed of as unusable waste [14].

The famous phenomenon of the "French paradox" [21], implies that the consumption of wine reduces the incidence of degenerative diseases (especially heart disease [22]), a strong synergetic activity of grape ingredients, which improves and intensifies the benefits of bioactive compounds. Consequently, the attention of the industry and scientific community has increased towards extraction, analyzing and application of the bioactive compounds [14].

EPR (Electron Paramagnetic Resonance) and UHPLC (Ultra-High Performance Liquid Chromatography) research are currently being undertaken to investigate the qualitative and quantitative composition of grape skin extracts and their antioxidant/antiradical activity. The raw materials (Cabernet Sauvignon, Pinot Blanc, Morava, and Muscat Ottonel) for the extractions in absolute $\mathrm{EtOH}$, $50 \% \mathrm{EtOH}$, and $\mathrm{H}_{2} \mathrm{O}$ were delivered from winery „Despotika”. Since the winery industry regularly disposes of huge quantities of grape pomace as an environmental burden, this study was oriented towards wine grapes. Instead of using artificially synthesized active compounds or isolating and concentrating from single to few naturally occurring active compounds (purified extracts), we decided to use grape skin extracts as originally obtained (complete/crude extracts). The main advantages of using complete grape skin extracts reflect in their ability to maintain biological activity in a similar form as in their natural environment, expressing synergistic effect and biocompatibility. For basic and instantaneous evaluation of the grape skin extracts activity, we have investigated the in vitro DPPH radical scavenging using EPR spectroscopy. Accordingly, we expect to develop low-priced, environmentally friendly, health-improving products from grape extracts. 
The aim of this study was to compare redox properties of absolute $\mathrm{EtOH}, 50 \% \mathrm{EtOH}$, and $\mathrm{H}_{2} \mathrm{O}$ grape wine skin extracts in a way of scavenging DPPH radicals, showing that biowaste obtained from grape wineskins could be used as an immense source of bioactive compounds with high antiradical activity.

\section{MATERIAL AND METHODS}

\section{Reagents}

Ethanol (EtOH), manufactured by Merck KGaA (Germany), and 2,2-diphenyl-1-picrylhydrazyl (DPPH), manufactured by Sigma (Germany), were of analytical grade. Solvents for LC-MS analyses (acetonitrile and formic acid), obtained from Fisher Scientific (Loughborough, UK), were HPLC or LC-MS grade. Ultrapure water was generated by deionization (Millipore, Billerica, USA). Standards of phenolics (syringic, protocatechuic, vanillic, cinnamic, 3-O-caffeoylquinic, caffeic, rosmarinic and ferulic acids; aesculin, luteolin, apigenin, chrysin, rutin, quercetin, kaempferol, galangin, naringenin, hesperidin and pinocembrin) were purchased from Sigma-Aldrich (Steinheim, Germany).

\section{Sample preparation}

Pressed marcs (pomace) were collected immediately after pressing and before vinification from a winemaking company near Smederevska Palanka, Serbia. Grape seeds were manually removed, and the samples were dried in the dehydrator at $60{ }^{\circ} \mathrm{C}$ up to reaching the moisture content of $\max 4 \%$ (determined by dry weight in oven at $105^{\circ} \mathrm{C}$ until constant weight) [23]. Dried skins were milled by a grinder shortly before the extraction. Grinding was carried out in $10 \mathrm{~s}$ intervals followed by $30 \mathrm{~s}$ breaks, to avoid overheating [24]. The obtained powder was passed through the 100 mesh sieve. Hydroethanolic extraction was performed by mixing the grape skin powder with the $50 \% \mathrm{EtOH}$ in $1 / 10(\mathrm{w} / \mathrm{v})$ ratio in an Erlenmeyer flask [23]. The flasks were capped and placed onto the orbital shaker (200 rpm), and the extraction was carried out in the incubator at $50{ }^{\circ} \mathrm{C}$ for $5 \mathrm{~h}[23,25,26]$. The suspended solids were removed from the extracts by vacuum filtration through the qualitative filter paper, additionally followed by centrifugation at $4500 \mathrm{~g}$ for $10 \mathrm{~min}$ and subsequent separation of the supernatant $[23,25]$. All of the extracts were passed through the $0.2 \mu \mathrm{m}$ filter. The samples were kept in dark at $-80{ }^{\circ} \mathrm{C}$ until further analysis. The same procedure was repeated for extraction in deionized water, as well as in absolute EtOH.

\section{Determination of the scavenging activity toward the DPPH radicals}

DPPH compound is a readily available stable free radical widely used in studying the antioxidant capacity of various compounds, especially by the means of UV-Vis spectroscopy. Standard DPPH assays are based on the reduction of the violet EtOH solution of its free radical form to the colorless (to yellow) form in the presence of antioxidant molecules [27]. On the other hand, DPPH radical is suitable for EPR assays as well, since its radical form is EPR active and the reduced form is EPR silent. EPR methods are the preferred ones, especially because they do not rely on the optical characteristics of the studied system. The distinctive EPR signal of DPPH radical enables the estimation of the initial radical concentration and the potential of the grape skin extracts to reduce its presence in the system [28].

Samples were studied by adapting the previously developed method $[28,29]$ to detect the activity of grape skin extracts toward the DPPH radicals. In brief, $1 \mu$ of grape skin extract was added to the $29 \mu \mathrm{l}$ of the $210 \mu \mathrm{M}$ $\mathrm{DPPH}$ solution in the appropriate solvent (absolute $\mathrm{EtOH}, 50 \% \mathrm{EtOH}$ and $\mathrm{H}_{2} \mathrm{O}$ ). The mixture was transferred into the gas-permeable Teflon tube, and the EPR signal was recorded upon 2 min using Bruker ELEXSYS-II E540 spectrometer operating in X-band, under the following experimental settings: center field $3500 \mathrm{G}$, microwave power $10 \mathrm{~mW}$, microwave frequency $9.85 \mathrm{GHz}$, modulation frequency $100 \mathrm{kHz}$, modulation amplitude $2 \mathrm{G}$. Control recording was made by substituting the samples with the same volume of the corresponding solvent.

\section{Quantification of the polyphenolics using UHPLC-DAD MS/MS}

Separation, determination, and quantifica- 
tion of the components in the wine grape skin extracts were performed using a Dionex Ultimate 3000 UHPLC system equipped with a diode array detector (DAD) that was connected to a TSQ Quantum Access Max triplequadrupole mass spectrometer (Thermo Fisher Scientific, Basel, Switzerland). The elution was performed at $40{ }^{\circ} \mathrm{C}$ on a Syncronis $\mathrm{C} 18$ column $(100 \times 2.1 \mathrm{~mm})$ with $1.7 \mu \mathrm{m}$ particle size (Thermo Fisher Scientific, Fair Lawn, NJ, USA). The mobile phase consisted of (A) $0.1 \%$ aqueous formic acid solution, and (B) acetonitrile, which was applied in the following gradient elution: $5 \% \mathrm{~B}$ in the first $\mathrm{min}, 5-95 \%$ B for $1.0-14.0 \mathrm{~min}$, from $95 \%$ to $5 \%$ B at 14.0 min and 5\% B until the $20.4 \mathrm{~min}$. The flow rate was set to $0.3 \mathrm{ml} \mathrm{min}^{-1}$ and the detection wavelengths to 254 and $280 \mathrm{~nm}$. The injection volume was $5 \mu$ l. Samples were filtered through a $0.45 \mu \mathrm{m}$ membrane filter to be analyzed by UHPLC-HESI-MS/MS.

A TSQ Quantum Access Max triplequadrupole mass spectrometer equipped with heated electrospray ionization (HESI) source was used as the detector and the ion source settings were the same as in literature [30]. The mass spectrometer was set to negative mode. HESI-source parameters were as follows: capillary temperature $275^{\circ} \mathrm{C}$, vaporizer temperature $250^{\circ} \mathrm{C}$, spray voltage $\pm 4500 \mathrm{~V}$, sheath and auxiliary gas flow $\left(\mathrm{N}_{2}\right) 27$ and 7 (arbitrary

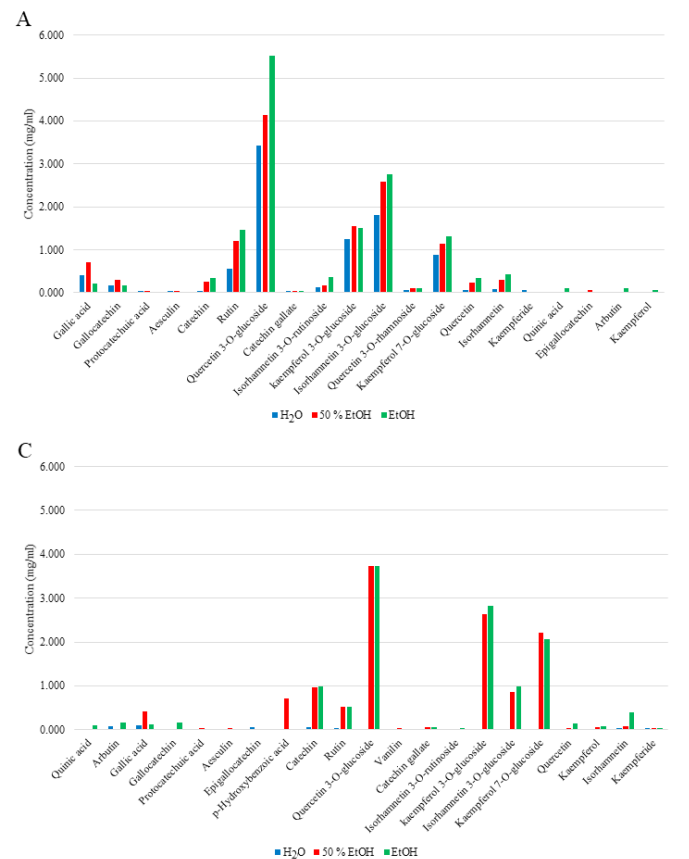

units). MS spectra were acquired by full range acquisition covering 100-900 m/z. For fragmentation study, a data-dependent scan was performed by deploying the collision-induced dissociation (CID). The normalized collision energy of the collision-induced dissociation (CID) cell was set at $35 \mathrm{eV}$.

The mass spectrometry data were acquired in the positive and negative mode, in the $\mathrm{m} / \mathrm{z}$ range from 100 to 1000 . Multiple mass spectrometric scanning modes, including full scanning (FS), and product ion scanning (PIS) were conducted for qualitative analysis of the targeted compounds. The collision-induced fragmentation experiments were performed using argon as the collision gas, and the collision energy was varied depending on the compound. The time-dependent selected reaction monitoring (t-SRM) experiments for quantitative analysis were performed using two MS/ MS fragments for each compound that were previously defined as dominant in the PIS experiments.

Xcalibur software 2.2 (Thermo Fisher Scientific, Bremen, Germany) was used for instrument control. The phenolics were quantitated by direct comparison with commercial standards. The total amounts of each compound were evaluated by calculation of the peak areas and expressed in $\mathrm{mg} / \mathrm{l}$.

Preparation of standard solutions: A

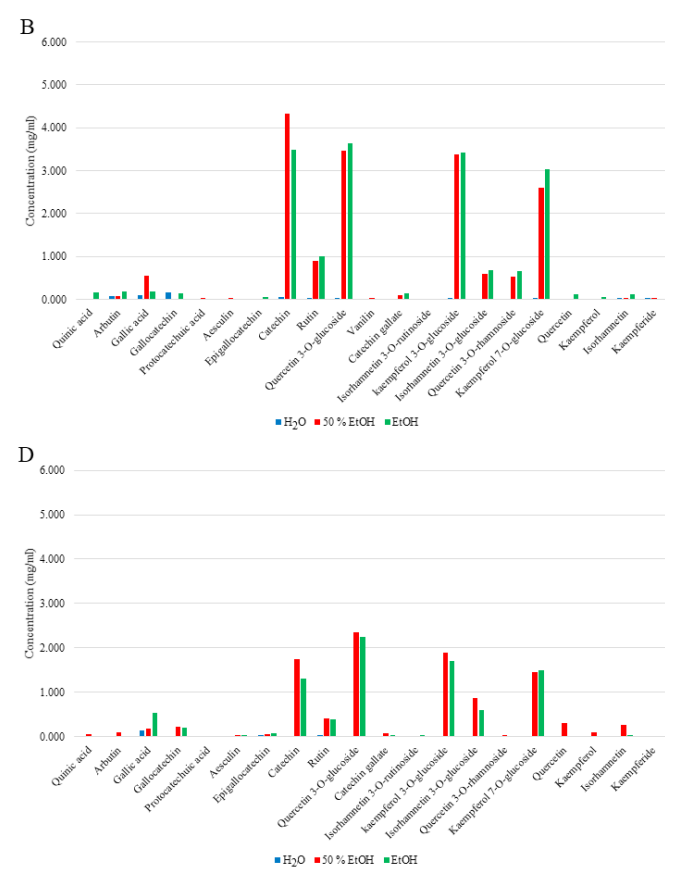

Figure 1. The composition of selected grape-skin extracts obtained in $\mathrm{H}_{2} \mathrm{O}, 50 \%$ EtOH and $\mathrm{EtOH}$, for Cabernet Sauvignon (A), Pinot Blanc (B), Morava (C) and Muscat Ottonel (D). 
$1000 \mathrm{mg} / \mathrm{l}$ stock solution of a mixture of all phenolic standards was prepared in methanol. Dilution of the stock solution with methanol yielded the working solutions in following concentrations $0.025,0.050,0.100,0.250,0.500$, 0.750 , and $1.000 \mathrm{mg} / \mathrm{l}$. Calibration curves were obtained by plotting the peak areas of the standards against their concentration. Calibration curves revealed good linearity, with $\mathrm{r}^{2}$ values exceeding 0.99 (peak area vs. concentration).

This paper is part of Academic (noncommercial) study.

\section{RESULTS}

\section{HPLC analysis}

Results obtained using HPLC analysis show-

Figure 2. EPR spectra of the control sample and the selected grape skin extracts obtained in absolute $\mathrm{EtOH}(\mathrm{A}), 50 \% \mathrm{EtOH}$ (B) and $\mathrm{H}_{2} \mathrm{O}(\mathrm{C})$, recorded $2 \mathrm{~min}$ upon the addition of DPPH into the system. Cabernet Sauvignon (absolute $\mathrm{EtOH}$ and $50 \%$ EtOH) and Pinot Blanc (50\% $\mathrm{EtOH}$ ) grape skin extracts were diluted $9 \times$ prior to the recordings.

Table 1. Anti-DPPH activity of the selected grape skin extracts calculated from the normalized double integral values. Results for $9 \times$ diluted samples are designated by asterisk.

A

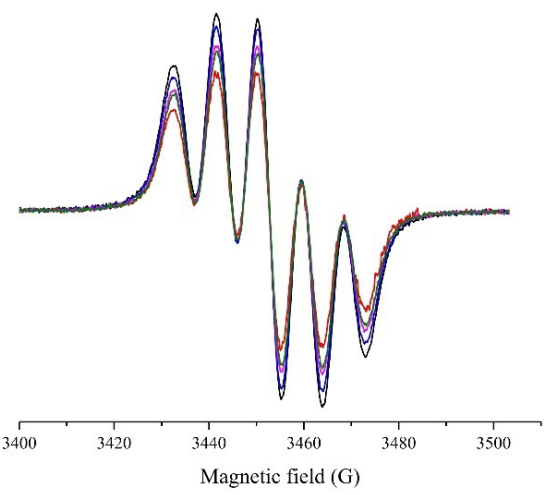

C

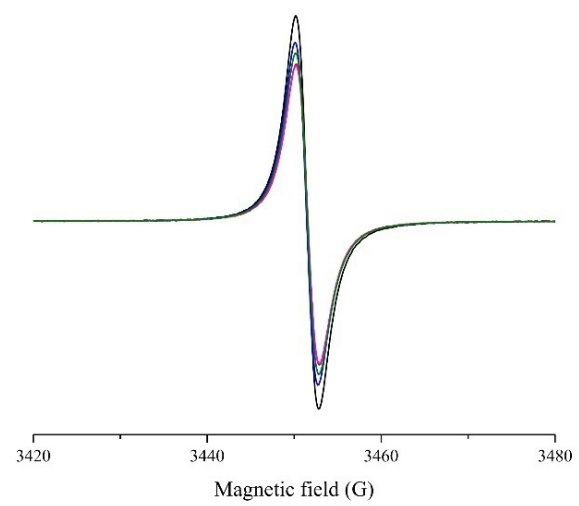

ing concentrations of detected components (in $\mathrm{mg} / \mathrm{ml}$ ) for selected $\mathrm{H}_{2} \mathrm{O}, 50 \% \mathrm{EtOH}$ and absolute $\mathrm{EtOH}$ extracts are presented in Figure 1.

\section{EPR spectroscopy}

EPR spectra obtained 2 minutes upon the interaction of DPPH with the grape skin extracts are shown in Figure 2.

After the initial experiments were performed, the results indicated that Cabernet Sauvignon (absolute EtOH and 50\% EtOH), as well as Pinot Blanc (50\% EtOH) grape skin extracts had an absolute DPPH radical scavenging potential for the selected concentration of DPPH. For this reason, these extracts were diluted 9 times, and the recordings were repeated. The anti-DPPH activity (AA) of the

B

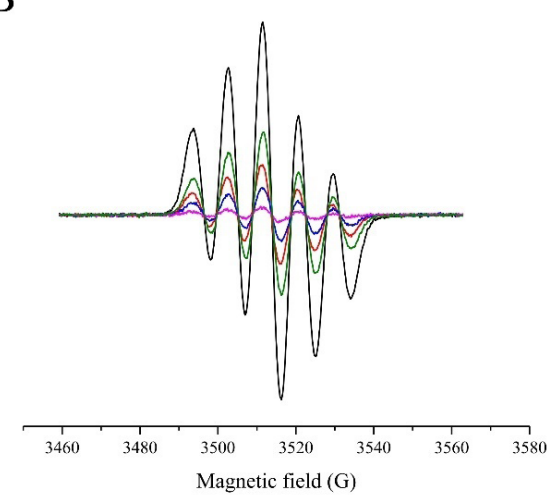

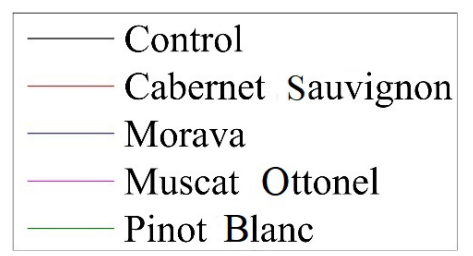

\begin{tabular}{|l|c|c|c|}
\hline \multirow{2}{*}{ Grape skin extract } & \multicolumn{3}{|c|}{ Anti-DPPH activity (\%) in designated solvent } \\
\cline { 2 - 4 } & EtOH & $50 \%$ EtOH & $\mathrm{H}_{2} \mathrm{O}$ \\
\hline Cabernet Sauvignon & $31.26^{*}$ & $75.38^{*}$ & 19.41 \\
\hline Pinot Blanc & 22.24 & $58.46^{*}$ & 15.10 \\
\hline Muscat Ottonel & 18.78 & 96.28 & 17.67 \\
\hline Morava & 7.30 & 85.66 & 15.06 \\
\hline
\end{tabular}




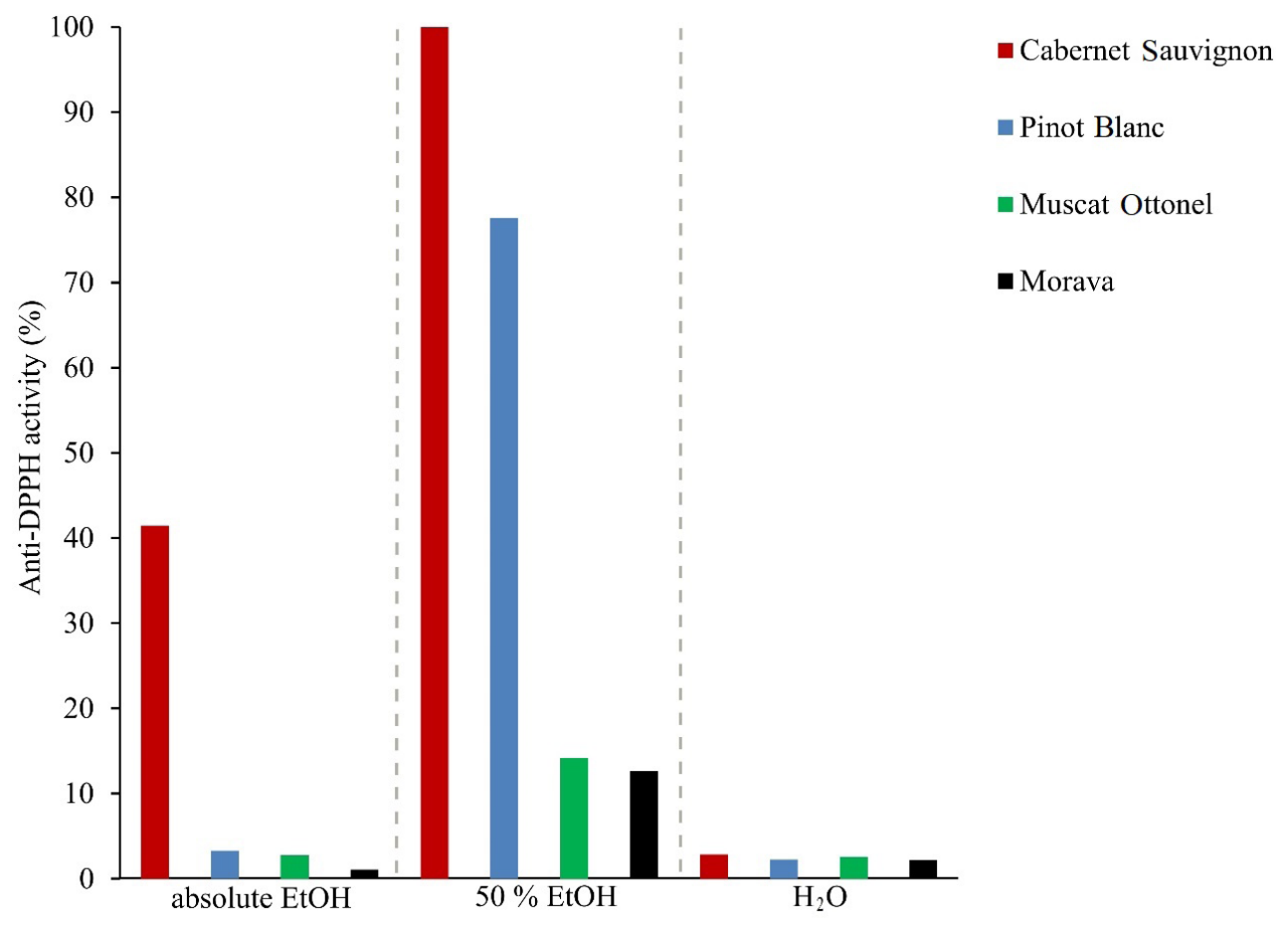

grape skin extracts was calculated using the formula [29]:

$$
A A=\frac{I_{c}-I_{a}}{I_{C}} 100(\%)
$$

where Ic and Ia refer to the double integral values of the control and samples determined from the EPR spectra (using Xepr software), respectively. The calculated anti-DPPH activities of the extracts are presented in Table 1.

To present data more clearly (due to the dilution factor) anti-DPPH activities presented in Figure 3 were normalized to the highest value (Cabernet Sauvignon in 50\% EtOH).

\section{DISCUSSION}

Previous studies indicate that grape pomace have remarkable antioxidant potential, strongly suggesting that they should be reprocessed rather than put to biowaste. Red grape cultivars generally have high content of anthocyanins and flavonols and are proved to be highly active free radical scavengers [31]. Pomace from the red wine cultivars is proved to contain significant amount of polyphenols after the vinification process, sufficient to exert anti-hypertension effects in vivo in hypertensive rats [32]. Another study on rats showed that administration of grape pomace extracts rich in anthocyanins, anthocyanidins, phenolic acids and flavonols actually induced oxidative stress, which could potentially trigger the response of body antioxidant mechanisms [33]. Most of the available studies are focused on red grape pomace polyphenols composition, while white varieties draw little attention [34]. While the entire grape mass is used for the fermentation of red wine, only the juice is used to produce white wines, which leads to significant grape pomace composition variations, making valorization rather difficult [35]. Pomace from the white grape cultivars is rich in dietary fibers and has a high total polyphenolic content [36]. Likewise, white grape pomace extracts are rich in phenols, flavanols, flavonoids and tannins, and show antioxidant, anti-tyrosinase and anti-inflammatory effects $[34,37]$. Depending on the white grape variety, most of the pomace extracts have a high content of catechin, epicatechin and procyanidin B2 [34]. Both red and white grape pomace extracts showed the potential to suppress hyperglycemia in diabetic mice, with red grape pomace extracts exerting a higher suppression effect, but also being richer in total phenolic content [38]. Grape pomace can be incorporated in plant, meat, fish and dairy products, since dietary fibers and polyphenols could increase the nutritional value and oxidative stability of the final products $[36,39]$.
Figure 3. Anti-DPPH activities of grape skin extracts scaled to the activity of Cabernet Sauvignon in $50 \% \mathrm{EtOH}$. 
In this study, the obtained results indicate that hydroethanolic grape skin extracts possess the highest DPPH scavenging potential. This is in accordance with the fact that hydroethanolic extraction of phenolic compounds is more efficient compared to the extraction performed using corresponding mono-component solvents [23, 40]. As it could be observed, Cabernet Sauvignon grape skin extracts have overall the highest potential to remove DPPH radicals from the system. This finding correlates well with previous reports of red grape varieties having higher polyphenolic content compared to white grape varieties [41, 42].

Having in mind the concentration of redox-active components obtained by HPLC analysis and presented EPR results, there is strong evidence that primarily quercetin 3-Oglucoside as well as kaempferol 3-O-glucoside, isorhamnetin 3-O-glucoside, kaempferol 7-Oglucoside supplemented with catechin and rutin, are responsible for the antioxidative capacity of extracts. It could also be observed that the largest quantity of most redox-active components could be found in absolute $\mathrm{EtOH}$ extracts, and that $\mathrm{H}_{2} \mathrm{O}$ extracts generally contain considerably lower amount of active constituents.

Even though anti-DPPH activity is up-to-date one of the most used indicators of free radical scavenging activity of target compounds, it should be noted that this approach has its limitations related to the ability of translation of obtained results to short-lived free radical species like ROS and RNS.

Although it is obvious that Cabernet Sauvignon is the most active towards elimination of stable DPPH radical, it would be interesting to identify how selected extracts are capable to remove biologically relevant shortlived radical species such as ${ }^{\circ} \mathrm{OH}$ and ${ }^{\circ} \mathrm{O}_{2}{ }^{-}$, as well as how they perform in the vicinity of $\mathrm{NO}^{\circ}$ and Asc' radicals.

\section{CONCLUSION}

$50 \% \mathrm{EtOH}$, absolute $\mathrm{EtOH}$ and $\mathrm{H}_{2} \mathrm{O}$ extracts, obtained from the grape skins, initially intended as biowaste, have shown high antiradical activity. Among all investigated grape varieties from the Šumadija region, Cabernet Sauvignon and Pinot Blanc exhibit the highest potential to remove DPPH radicals, which sets them as effective natural resources for pharma industry. HPLC analysis shows that primarily quercetin 3-O-glucoside as well as other detected redox-active components are responsible for the antioxidative capacity of extracts. EPR analysis shows that the largest quantity of the most redox-active components could be found in $50 \% \mathrm{EtOH}$ extract, which we propose to be the starting material for making potent redox-active cosmetic products and dietary supplements.

\section{CONFLICTS OF INTEREST}

All authors declare no conflict of interest.

\section{ACKNOWLEDGEMENT}

The authors thank Veselin Despotović and Darko Pejović (Despotika wine-making factory, Vlaški Do, Republic of Serbia) for kindly providing the pressed marcs required for this study. UHPLC/DAD/MS2 analysis was performed at the Department of Plant Physiology of the Institute for Biological Research "Siniša Stankovic" - National Institute of the Republic of Serbia, University of Belgrade. The authors thank Dr. Danijela Mišić and Dr. Uroš Gašić for their professional help. The financial support for this project was provided by the Ministry of Education, Science and Technological Development of the Republic of Serbia Contract number: 451-03-9/2021-14/200146.

\section{REFERENCES}

1. Nayak A, Bhushan B, Gupta V, Rodriguez-Turienzo L. Development of a green and sustainable clean up system from grape pomace for heavy metal remediation, J Environ Chem Eng. 2016 Dec; 4: 4342-53. Available from: DOI: 10.1016/j.jece.2016.10.001

2. Zacharof MP. Grape Winery Waste as Feedstock for Bioconversions: Applying the Biorefinery Concept. Waste Biomass Valor. 2016 Aug; 8: 1011-25. Available from: DOI: 10.1007/s12649-016-9674-2

3. Fernández-Puratich $\mathrm{H}$, Hernández $\mathrm{D}$, Tenreiro $\mathrm{C}$. Analysis of energetic performance of vine biomass residues as an alternative fuel for Chilean wine industry. Renew Energ. 2015 Nov; 83: 1260-67. Available from: DOI: 10.1016/j.renene.2015.06.008

4. Filho MG, Lumi M, Hasan C, Marder M, Leite LCS. Konrad O. Energy recovery from wine sector wastes: A study about the biogas generation potential in a vineyard from Rio Grande do Sul. Brazil Sustain Energy Techn. 2018 Oct; 29: 44-9. Available from: DOI: 10.1016/j.renene.2015.06.008

5. Kalli E, Lappa I, Bouchagier P, Tarantilis PA, Skotti 
E. Novel application and industrial exploitation of winery by-products. Bioresour Bioprocess. 2018 Nov; 5(46). Available from: DOI: 10.1186/s40643018-0232-6

6. Lupoli R, Ciciola P, Costabile G, Giacco R, Di MinnoMND, Capaldo B. Impact of Grape Products on Lipid Profile: A Meta-Analysis of Randomized Controlled Studies. J Clin Med. 2020 Jan; 9(2): 313. Available from: DOI: $10.3390 / \mathrm{jcm} 9020313$

7. Vislocky LM, Fernandez ML. Biomedical effects of grape products. Nutr Rev. 2010 Nov; 68(11): 656-70. Available from: DOI: $10.1111 / \mathrm{j} .1753-$ 4887.2010.00335.x

8. Zillich OV, Schweiggert-Weisz U, Eisner P, Kerscher $M$. Polyphenols as active ingredients for cosmetic products. Int J CosmetSci. 2015 Feb; 37(5): 455-64. Available from: DOI: $10.1111 /$ ics. 12218

9. Balea SS, Pârvu AE, Pârvu M, Vlase L, Dehelean CA, Pop TI. Antioxidant, Anti-Inflammatory and Antiproliferative Effects of the Vitisvinifera L. var. Fetească Neagră and Pinot Noir Pomace Extracts. Front Pharmacol. 2020 July; 11: 990. Available from: DOI: 10.3389/fphar.2020.00990

10. luga $M$, Mironeasa S. Potential of grape byproducts as functional ingredients in baked goods and pasta. Compr Rev Food Sci Food Saf. 2020 July;19: 2473-505. Available from: DOI: 10.1111/15414337.12597

11. Libera J, Latoch A, Wójciak KM. Utilization of Grape Seed Extract as a Natural Antioxidant in the Technology of Meat Products Inoculated with a Probiotic Strain of LAB. Foods. 2020 Jan; 9(1): 103. Available from: DOI: 10.3390/foods9010103

12. Hassan YI, Kosir V, Yin X, Ross K, Diarra MS. Grape Pomace as a Promising Antimicrobial Alternative in Feed: A Critical Review. J Agric Food Chem. 2019 Aug; 67(35): 9705-18. Available from: DOI: 10.1021 /acs.jafc. 9 b02861

13. Teixeira A, Baenas N, Dominguez-Perles R, Bar$\operatorname{ros}$ A, Rosa E, Moreno DA, Garcia-Viguera C. Natural Bioactive Compounds from Winery By-Products as Health Promoters: A Review. Int J Mol Sci. 2014 Sep; 15(9): 15638-78. Available from: DOI: 10.3390/ ijms150915638

14. Galanakis CM, editor. Handbook of Grape Processing By-Products. 1st ed. Elsevier: Nikki Levy; 2017.

15. Janković SM, Milovanović DR, Janković SV. Schild's equation and the best estimate of pa2 value and dissociation constant of an antagonist. Croatian Med J. 1999; 40 (1): 67-70.

16. Ko J-L, Tsai C-H, Liu T-C, Lin M-Y, Lin H-L, Ou $C-C$. Differential effects of grape juice on gastric emptying and renal function from cisplatininduced acute adverse toxicity. Hum Exp Toxicol. 2016 Aug; 35(8): 808-17. Available from: DOI: $10.1177 / 0960327115607079$
17. Kastratović DA, Vasiljević ZM, Spasić $M B$, Peruničić JP, Matić M, Blagojević DP, Mijalković DN, Antonijević NM, Marković SZ, Gojković-Bukarica Lj, Stojiljkovic MP, Lasica RM, Jones DR, Nikolić-Kokić AL. Carvedilol increases copper-zinc superoxide dismutase activity in patients with acute myocardial infarction. Basic Clin Pharmacol Toxicol, 2007;101(2):138-42.

18. Ruan $\mathrm{Y}$, Jin $\mathrm{Q}$, Zeng J, Ren F, Xie Z, Ji K, Wu L, Wu J, Li L. Grape Seed Proanthocyanidin Extract Ameliorates Cardiac Remodelling After Myocardial Infarction Through PI3K/AKT Pathway in Mice. Front Pharmacol 2020 Dec; 11: 585984. Available from: DOI: 10.3389/fphar.2020.585984

19. Bugarcić ZD, Petrović B, Bugarcić ZM, Janković $S M$, Janković SV, Lukić G, et al. Effects of cisplatin and other Pt(II) complexes on spontaneous motility of isolated human oviduct. Toxicol In Vitro. 2008 Dec; 22: 1878-82. Available from: DOI: $10.1016 / \mathrm{j}$. tiv.2008.09.011

20. Hsia S-M, Wang K-L, Wang PS. Effects of resveratrol, a grape polyphenol, on uterine contraction and $\mathrm{Ca}^{2}+$ mobilization in rats in vivo and in vitro. Endocrinology. 2011 May; 152(5): 2090-9. Available from: DOI: 10.1210/en.2010-1223

21. Burr ML. Explaining French paradox. J Roy Soc Health. 1995 Aug; 115(4): 217-9. Available from: DOI: $10.1177 / 146642409511500404$

22. Haseeb S, Alexander B, Baranchuk A. Wine and Cardiovascular Health: A Comprehensive Review. Circulation 2017 Oct; 136(15): 1434-48. Available from: DOI: 10.1161/CIRCULATIONAHA.117.030387

23. Spigno G, Tramelli L, De Faveri DM. Effects of extraction time, temperature and solvent on concentration and antioxidant activity of grape marc phenolics. J Food Eng. 2007 July; 81(1):200-8. Available from: DOI: 10.1016/j.jfoodeng.2006.10.021

24. Duba KS, Casazza AA, Mohamed H Ben, Perego P, Fiori L. Extraction of polyphenols from grape skins and defatted grape seeds using subcritical water: Experiments and modeling. Food Bioprod Process. 2015 Apr; 94:29-38. Available from: DOI: 10.1016/j. fbp.2015.01.001

25. Caldas TW, Mazza KEL, Teles ASC, Mattos GN, Brígida AIS, Conte-Junior CA, et al. Phenolic compounds recovery from grape skin using conventional and non-conventional extraction methods. Ind Crops Prod. 2018 Jan; 111:86-91. Available from:DOI: 10.1016/j.indcrop.2017.10.012

26. Li J, Zhang S, Zhang M, Sun B. Novel approach for extraction of grape skin antioxidants by accelerated solvent extraction: Box-Behnken design optimization. J Food Sci Technol. 2019 Aug;56(11):4879-90. Available from: DOI: 10.1007/s13197-019-03958-5

27. Huang D, Boxin OU, Prior RL. The chemistry behind antioxidant capacity assays. J Agric Food Chem. 2005 Feb; 53(6):1841-56. Available from:DOI: $10.1021 / \mathrm{jf030723C}$ 
28. Sanna D, Delogu G, Mulas M, Schirra M, Fadda A. Determination of Free Radical Scavenging Activity of Plant Extracts Through DPPH Assay: An EPR and UV-Vis Study. Food Anal Methods. 2011 Oct; 5(4):759-66. Available from: DOI: 10.1007/s12161011-9306-1

29. Gođevac D, Vujisić L, Mojović M, Ignjatović A, Spasojević I, Vajs V. Evaluation of antioxidant capacity of Allium ursinum L. volatile oil and its effect on membrane fluidity. Food Chem. 2008 Apr; 107(4):1692-700. Available from: DOI: $10.1016 / \mathrm{j}$. foodchem.2007.10.017

30. Mišić D, Šiler B, Gašić U, Avramov S, Živković $S$, NestorovićŽivković J, Milutinović M, Tešić Ž. Simultaneous UHPLC/DAD/(+/-)HESI-MS/MS Analysis of Phenolic Acids and Nepetalactones in Methanol Extracts of Nepeta Species: A Possible Application in Chemotaxonomic Studies. Phytochem Anal. 2014 Nov; 26(1): 72-85. Available from:DOI: 10.1002/ pca. 2538

31. Ruberto G, Renda A, Daquino C, Amico V, Spatafora C, Tringali C, De Tommasi N. Polyphenol constituents and antioxidant activity of grape pomace extracts from five Sicilian red grape cultivars. Food Chem. 2007 Nov; 100(1): 203-210. Available from: DOI: $10.1016 /$ j.foodchem.2005.09.041

32. Rasines-Perea Z, Ky I, Cros G, Crozier A, Teissedre P-L. Grape Pomace: Antioxidant Activity, Potential Effect Against Hypertension and Metabolites Characterization after Intake. Diseases. 2018 Jul; 6(3): 60. Available from: DOI: $10.3390 /$ diseases6030060

33. Veskoukis AS, Kyparos A, Nikolaidis MG, Stagos D, Aligiannis N, Halabalaki M, Chronis K, Goutzourelas N, Skaltsounis L, Kouretas D. The antioxidant effects of a polyphenol-rich grape pomace extract in vitro do not correspond in vivo using exercise as an oxidant stimulus. Oxid Med Cell Longev. 2012 Mar; 185867. Available from: DOI: 10.1155/2012/185867

34. González-Centeno MR, Jourdes M, Femenia A, Simal S, Rosselló C, Teissedre PL. Characterization of polyphenols and antioxidant potential of white grape pomace byproducts (Vitis vinifera L.). J Agric Food Chem. 2013 Nov; 61(47): 11579-11587. Available from: DOI: $10.1021 /$ jf $403168 \mathrm{k}$

35. Jin Q, Hair JO, Stewart AC, Keefe SFO, Neilson AP, Kim Y, McGuire $M$, Lee A, Wilder G, Huang $H$. Industrial White and Red Grape Pomaces in Virginia Major Components. Foods. 2019 Dec; 8(12): 667. Available from: DOI: 10.3390/foods 8120667

36. Sánchez-Alonso I, Jiménez-Escrig A, SauraCalixto F, Borderías AJ. Antioxidant protection of white grape pomace on restructured fish products during frozen storage. LWT - Food Sci Technol. 2008 Feb; 41(1): 42-50. Available from: DOI: 10.1016/j. Iwt.2007.02.002

37. Ferri M, Rondini G, Calabretta MM, Michelini E, Vallini V, Fava F, Roda A, Minnucci G, Tassoni A. White grape pomace extracts, obtained by a sequential enzymatic plus ethanol-based extraction, exert antioxidant, anti-tyrosinase and anti-inflammatory activities. N Biotechnol. 2017 Jul; 39: 5158. Available from: DOI: 10.1016/j.nbt.2017.07.002

38. Hogan S, Zhang L, Li J, Sun S, Canning C, Zhou K. Antioxidant rich grape pomace extract suppresses postprandial hyperglycemia in diabetic mice by specifically inhibiting alpha-glucosidase. Nutr Metab. 2010 Aug; 7:71. Available from: DOI: 10.1186/1743-7075-7-71

39. Antonić B, Jančíková S, Dordević D, Tremlová B. Grape Pomace Valorization: A Systematic Review and Meta-Analysis. Foods. 2020 Nov; 9(11): 1627. Available from: DOI: $10.3390 /$ foods 9111627

40. Shi J, Yu J, Pohorly J, Young JC, Bryan M, Wu Y. Optimization of the extraction of polyphenols from grape seed meal by aqueous ethanol solution. J Food Agric Environ. 2003 Apr; 1(2): 42-47. Available from: DOI: 10.1234/4.2003.337

41. Dani C, Oliboni LS, Vanderlinde R, Bonatto D, Salvador $M$, Henriques JAP. Phenolic content and antioxidant activities of white and purple juices manufactured with organically- or conventionallyproduced grapes. Food ChemToxicol. 2007 Dec; 45(12): 2574-80. Available from:DOI: 10.1016/j. fct.2007.06.022

42. Burin VM, Falcão LD, Gonzaga LV, Fett R, Rosier JP, Bordignon-Luiz MT. Colour, phenolic content and antioxidant activity of grape juice. Ciência e Tecnol Aliment. 2010 Oct-Dec; 30(4): 1027-32. Available from: DOI: 10.1590/S0101-20612010000400030 


\title{
Redoks svojstva ekstrakata pokožice vinskog grožđa iz šumadijskog kraja - Ispitivanje elektronskom paramagnetnom rezonacijom
}

\author{
Đura J. Nakarada ${ }^{1}$, Srđan Z. Marković ${ }^{1,2}$, Milan D. Popović́ ${ }^{1}$, Milena S. Dimitrijevićc \\ Aleksandra A. Rakić ${ }^{1}$, Miloš D. Mojović ${ }^{1}$ \\ ${ }^{1}$ Fakultet za fizičku hemiju, Univerzitet u Beogradu, Centar za fizičku hemiju bioloških sistema, Beograd, \\ Srbija \\ ${ }^{2}$ Klinički centar Srbije, Beograd, Srbija \\ ${ }^{3}$ Institut za multidisciplinarna istraživanja, Univerzitet u Beogradu, Beograd, Srbija
}

\section{KRATAK SADRŽAJ}

Uvod: Plodovi vinove loze obiluju jedinstvenim polifenolnim bioaktivnim jedinjenjima, a poznato je da grožđe ima blagotvorno dejstvo na celo telo. Ova jedinjenja pokazuju visoku antioksidativnu i antiradikalsku aktivnost posredstvom helacije teških metala, uklanjanja reaktivnih kiseoničnih vrsta, inhibicije lipidne peroksidacije i očuvanja integriteta ćelijskih membrana. U vinarskoj industriji, posle drobljenja i presovanja, komina grožđa (stabljike, seme, pulpa i pokožice) uklanja se kao nusproizvod. Ovaj dragoceni izvor bioaktivnih jedinjenja povremeno se koristi kao hrana za životinje, kompost, sirovina u pivari, ali se nažalost uglavnom odlaže kao neupotrebljiv otpad.

Cilj: Cilj ove studije je upoređivanje redoks svojstava ekstrakata pokožica vinove loze u apsolutnom EtOH, $50 \% \mathrm{EtOH} \mathrm{i}_{2} \mathrm{O}$, ispitivanjem sposobnosti uklanjanja DPPH radikala, kako bi se pokazalo da se biootpad dobijen od pokožica grožđa može koristiti kao značajan izvor bioaktivnih jedinjenja sa visokom antiradikalnom aktivnošću.

Metodologija: Elektronska paramagnetna rezonantna (EPR) spektroskopija upotrebljena je za ispitivanje aktivnosti ekstrakata pokožica grožđa prema DPPH radikalima, a UHPLC-DAD MS/MS analiza za razdvajanje, identifikaciju i kvantifikaciju njihovih aktivnih komponenti.

Rezultati: Dobijeni rezultati pokazuju da ekstrakti pokožica grožđa Cabernet Sauvignon i Pinot Blanc imaju značajan potencijal za uklanjanje DPPH radikala iz sistema. $\mathrm{Na}$ osnovu koncentracija redoks-aktivnih komponenti dobijenih UHPLC-DAD MS/MS analizom i rezultata EPR merenja, može se zaključiti da su kvercetin-3-0-glukozid, kempferol-3-0-glukozid, izoramnetin-3-0-glukozid, kempferol-7-0-glukozid, katehin i rutin glavni nosioci antioksidativne aktivnosti ekstrakata.

Zaključak: Ova studija pokazuje da ekstrakti dobijeni iz pokožica grožđa (inicijalno namenjenih biootpadu) pokazuju visoku antiradikalnu aktivnost. Najveća količina redoks-aktivnih komponenata može se naći u ekstraktima $50 \%$ EtOH, za koje predlažemo da budu polazni materijal za izradu snažnih redoks-aktivnih kozmetičkih proizvoda i dodataka ishrani.

Ključne reči: Ekstrakti pokožice grožđa, antioksidativna aktivnost, elektronska paramagnetna rezonacija, UHPLC-DAD MS/MS analiza 